Suska Journal of Mathematics Education (p-ISSN: 2477-4758 | e-ISSN: 2540-9670)

Vol. 3, No. 1, 2017, Hal. 57 - 00

\title{
Penerapan Model Pembelajaran Numbered Head Together (NHT) pada Siswa Kelas V SD Negeri 75 Ujungpero Kecamatan Sabbangparu Kabupaten Wajo
}

\author{
Wahyuddin ${ }^{1}$ \\ ${ }^{1}$ Dosen Universitas Muhammadiyah Makassar \\ e-mail :wahyu@unismuh.ac.id
}

\begin{abstract}
ABSTRAK: Tujuan penelitian ini adalah untuk mendeskripsikan hasil belajar matematika dengan penerapan pembelajaran kooperatif tipe Numbered Head Together siswa Kelas V SD Negeri 75 Ujungpero Kecamatan Sabbangparu Kabupaten Wajo. Penelitian ini merupakan penelitian tindakan kelas (Classroom Action Research) yang meliputi perencanaan, tindakan, observasi, dan refleksi yang selanjutnya tahap-tahap tersebut dirangkai pada siklus yang dilaksnakan pada siklus I dan siklus II. Subjek penelitian ini adalah siswa kelas V SD Negeri 75 Ujungpero Kecamatan Sabbangparu Kabupaten Wajo Tahun ajaran 2015/2016 sebanyak 10 orang yang terdiri atas 7 perempuan dan 3 laki-laki, jenis data yang digunakan adalah data kuantitatif dan data kualitatif. Hasil penelitian menunjukkan bahwa pembelajaran kooperatif tipe NHT cocok diterapkan pada siswa kelas V SD Negeri 75 Ujungpero Kecamatan Sabbangparu Kabupaten Wajo. Hal tersebut dapat dilihat dari meningkatnya hasil belajar siswa setelah diadakan pengembangan pembelajaran kooperatif tipe NHT, Hasil belajar yang diperoleh dari tes akhir siklus, pada akhir siklus I dengan skor rata-rata 64,50 dari skor ideal 100 dengan standar deviasi 14,03, sedangkan pada akhir siklus II dengan skor rata-rata 80 dari skor ideal 100 dengan standar deviasi 9,13, dan terjadi perubahan sikap siswa selama proses pembelajaran sesuai dengan hasil observasi yaitu dengan adanya penerapan model pembelajaran kooperatif tipe NHT dapat meningkatkan rasa percaya diri siswa untuk bertanya baik kepada guru maupun kepada temannya.
\end{abstract}

Keywords: Pembelajaran kooperatif tipe Numbered Head Together, hasil belajar

\section{PENDAHULUAN}

Matematika merupakan suatu bahan kajian yang memiliki objek abstrak dan dibangun melalui melalui proses penalaran deduktif, yaitu kebenaran suatu konsep diperoleh sebagai akibat logis dari kebenaran sebelumnya sehingga keterkaitan antar konsep dalam matematika bersifat sangat kuat dan jelas. Dalam pembelajaran matematika agar mudah dimengerti oleh siswa, proses penalaran induktif dapat dilakukan pada awal pembelajaran dan kemudian dilanjutkan dengan proses penalaran deduktif untuk menguatkan pemahaman yang sudah dimiliki oleh siswa (Depdiknas, 2003).

Matematika sekolah adalah matematika yang diajarkan di sekolah, yaitu matematika yang diajarkan di pendidikan dasar dan pendidikan menengah. Matematika sekolah tersebut terdiri atas bagian-bagian matematika yang dipilih guna menumbuhkembangkan kemampuan-kemampuan dan membentuk pribadi serta berpandu pada ilmu pengetahuan dan teknologi (Suherman, 2001). Hal ini menunjukkan bahwa matematika sekolah tetap memiliki ciri-ciri yang dimiliki matematika, yaitu objek kejadian yang abstrak serta berpola pikir deduktif konsisten.

Matematika berfungsi untuk mengembangkan kemampuan bernalar melalui kegiatan penyelidikan, eksplorasi, dan eksperimen, sebagai alat pemecahan masalah melalui pola pikir dan 
model matematika, serta sebagai alat komunikasi melalui simbol, tabel, grafik, diagram, dalam menjelaskan gagasan, melatih dan menumbuhkan cara berpikir secara sistematis, logis, kritis, kreatif dan konsisten. Serta mengembangkan sikap gigih dan percaya diri sesuai dalam menyelesaikan masalah (Depdiknas, 2003).

Proses belajar mengajar harus terjadi interaksi antara guru dan siswa, bukan hanya guru yang mempengaruhi siswa, tetapi siswa juga dapat mempengaruhi guru. Interaksi dalam proses belajar mengajar bukan hanya terjadi antara siswa, tetapi antara siswa dengan manusia sumber (yaitu orang yang bisa memberi informasi), dan antara siswa dengan media pembelajaran. Guru dituntut menguasai dan menggunakan dengan tepat model, metode, atau teknik pembelajaran dalam proses belajar mengajar agar tercapai tujuan pembelajaran yang diinginkan. Guru merupakan suatu faktor yang berperan penting dalam proses belajar siswa, meskipun tidak setiap perbuatan siswa merupakan akibat guru mengajar. Sebagai figur sentral guru harus mampu menetapkan setrategi pembelajaran yang tepat, sehingga dapat mendorong terjadinya perbuatan siswa yang aktif dan produktif dan efisien.

Berdasarkan hasil pengamatan di pada siswa klas V SD Negeri 75 Ujungpero Kecamatan Sabbangparu Kabupaten Wajo diperoleh di informasi bahwa kemampuan siswa dalam menyelesaikan soal-soal matematika masih sangat rendah, bahkan kelihatannya siswa merasa takut dan malu bertanya tentang materi yang belum diketahui pada saat pelajaran matematika. Hal ini mungkin dikarenakan penyajian materi matematika masih bersifat monoton dan membosankan, sehingga siswa kurang tertarik untuk belajar matematika. Dalam situasi seperti ini siswa merasa bosan karena kurangnya dinamika inovasi, kekreatifan dan siswa belum dilibatkan secara aktif sehingga siswa sulit untuk mengembangkan atau meningkatkan pembelajaran agar benar-benar berkualitas. Akibatnya hasil belajar matematika siswa masih dibawah rata-rata 6,0 berdasarkan nilai ujian semester. Lebih lanjut metode yang sering digunakan dalam proses pembelajaran pada mata pelajaran adalah metode ceramah, diskusi maupun pemberian tugas di dalam kelas. Pada metode ini guru hanya berceramah secara terus menerus yang cenderung meminimalkan keterlibatan siswa sehingga guru nampak lebih aktif.

Solusi agar seluruh siswa merasa menjadi bagian dalam proses belajar mengajar. Mengingat pentingnya matematika untuk pendidikan, maka perlu dicari jalan penyelesaian yaitu suatu cara mengelola proses belajar mengajar matematika sehingga matematika dapat dicerna dengan baik oleh siswa. Penerapan pembelajaran kooperatif tipe numbered head together merupakan. Menurut Rusman (2012:203) Pembelajaran kooperatif (cooperative learnig) merupakan bentuk pembelajaran dengan cara siswa belajar dan bekerja dalam kelompok-kelompok kecil secara kolaboratif yang anggotanya terdiri dari 4 sampai 6 orang dengan struktur kelompok yang bersifat heterogen. "Pembelajaran kooperatif merupakan salah satu model pembelajaran yang terstruktur dan sistematis, dimana kelompok-kelompok kecil bekerjasama untuk mencapai tujuan bersama".

Pembelajaran kooperatif numbered head together (NHT) adalah satu tipe pembelaran kooperatif yang menekankan pada struktur khusus yang dirancang untuk mempengaruhi pola interaksi siswa dan memiliki tujuan untuk meningkatkan penguasaan akademik. "Model pembelajaran kooperatif tipe numbered head together ini pertama kali dikembangkan Spenser Kagen untuk melibatkan bamyak siswa dalam menelaah materi yang tercakup dalam suatu pembelajaran tersebut”. Lorina (2012:9). Pembelajaran NHT merupakan tipe pembelajaran yang dirancang untuk mempengaruhi pola interaksi siswa dan memiliki tujuan untuk meningkatkan semangat semangat kerjasama dalam kelompok serta memberikan kesempatan kepada siswa untuk saling membagi ide-ide dan mendiskusikan jawaban yang paling tepat. Lorina (2012:9).

Numbered Head Together (NHT) adalah salah satu pendekatan struktural, untuk melibatkan lebih banyak siswa dalam menelaah materi yang tercakup dalam suatu pembelajaran dan mengecek pemahaman siswa terhadap isi materi pembelajaran tersebut. Menurut Muslimin, dkk (2000: 28), mengemukakan ada 4 langkah dalam pendekatan struktural numbered heads together (NHT), yaitu: pelabelan, mengajukan pertanyaan, berpikir bersama, dan menjawab. 


\section{METODE PENELITIAN}

Penelitian ini merupakan penelitian tindakan kelas (Classroom Action Research) yang berbasis kelas yang meliputi perencanaan, tindakan, observasi, dan refleksi yang selanjutnya tahap-tahap tersebut dirangkai pada siklus yang dilaksnakan pada siklus I dan siklus II. Subjek penelitian ini adalah siswa kelas V SD Negeri 75 Ujungpero Kecamatan Sabbangparu Kabupaten Wajo Tahun ajaran 2015/2016 sebanyak 10 orang yang terdiri atas 7 perempuan dan 3 laki-laki.

Jenis data yang digunakan adalah data kuantitatif dan data kualitatif yang terdiri dari hasil belajar dan angket observasi. Cara pengambilan data yaitu data hasil belajar diperoleh dengan memberikan tes kepada siswa dan data tentang situasi pembelajaran saat pelaksanaan tindakan diperoleh melalui format observasi. Data yang telah dikumpul dianalisis dengan menggunakan teknik analisis kuantitatif dan kualitatif. Untuk hasil belajar dianalisis kuantitatif menggunakan statistik deskriptif yang selanjutnya dianalisis dengan bantuan program analisis data komputer, sedangkan hasil observasi siswa dianalisis secara kualitatif dengan menggunakan teknik kategorisasi standar yang ditetapkan oleh ditetapkan oleh Departemen Pendidikan dan Kebudayaan (Salam, 2004:28), yaitu :

Tebel 1. Pedoman Interpretasi Hasil Penelitian

\begin{tabular}{cc}
\hline Interval & Kategori \\
\hline $0-34$ & Sangat Rendah \\
\hline $35-54$ & Rendah \\
\hline $55-64$ & Sedang \\
\hline $65-84$ & Tinggi \\
\hline $85-100$ & Sangat Tinggi \\
\hline
\end{tabular}

\section{HASIL PENELITIAN}

\section{Analisis Siklus I dan Siklus II}

\section{Siklus I}

a. Hasil Analisis Kuantitatif

Pada siklus I ini dilaksanakan tes hasil belajar yang berbentuk ulangan harian setelah penyajian materi selama 5 kali pertemuan. Adapun data skor hasil belajar siklus I dapat dilihat pada Tabel 2 berikut ini:

Tabel 2. Statistik Skor Hasil Belajar Siswa pada Siklus I

\begin{tabular}{cc}
\hline Statistik & Nilai statistik \\
\hline Jumlah siswa & 10 \\
\hline Skor ideal & 100 \\
\hline Nilai maksimum & 80 \\
\hline Nilai minimum & 40 \\
\hline Rentang skor & 40 \\
\hline Skor rata-rata & 64,50 \\
\hline Median & 67,50 \\
\hline Modus & 70,00 \\
\hline Standar deviasi & 14,03 \\
\hline
\end{tabular}

Dari Tabel 2. menunjukkan bahwa skor rata-rata hasil belajar matematika setelah diterapkan pembelajaran kooperatif tipe NHT pada siklus I adalah 64,50 dari skor ideal yang mungkin dicapai adalah 100. Dari skor rata-rata tersebut menunjukkan bahwa hasil belajar 
matematika siswa pada siklus I sebesar $64,50 \%$ yang tergolong, masih rendah. Hal ini disebabkan karena masih kurangnya perhatian siswa dengan melakukan kegiatan lain selama proses pembelajaran berlangsung.

Apabila skor hasil belajar siswa dikelompokkan ke dalam 5 kategori maka diperoleh distribusi frekuensi nilai seperti yang disajikan pada Tabel 3 berikut.

Tabel 3.Distribusi Frekuensi dan Persentase Hasil Belajar pada Siklus I

\begin{tabular}{cccc}
\hline Skor & Kategori & Frekuensi & Persentase (\%) \\
\hline $0-34$ & $\begin{array}{c}\text { Sangat } \\
\text { rendah }\end{array}$ & 0 & 0 \\
\hline $35-54$ & Rendah & 2 & 20,00 \\
\hline $55-64$ & Sedang & 6 & 60,00 \\
\hline $65-84$ & Tinggi & 2 & 20,00 \\
\hline $85-$ & Sangat tinggi & 0 & 0 \\
100 & & 10 & 100 \\
\hline \multicolumn{2}{c}{ Jumlah } & & \\
\hline
\end{tabular}

Dari Tabel 3 menunjukkan bahwa skor rata-rata hasil belajar siswa setelah diberi tindakan pada siklus I berada pada kategori rendah.Apabila hasil belajar siswa pada siklus I dianalisis, maka persentase ketuntasan belajar siswa pada siklus I dapat dilihat pada Tabel 4 berikut.

Tabel 4. Deskripsi Ketuntasan Belajar Siswa pada Siklus I

\begin{tabular}{cccc}
\hline $\begin{array}{c}\text { Persentase } \\
\text { skor }\end{array}$ & Kategori & Frekuensi & $\begin{array}{c}\text { Persentase } \\
\mathbf{( \% )}\end{array}$ \\
\hline $0 \%-64 \%$ & Tidak tuntas & 2 & 20 \\
\hline $65 \%-100 \%$ & Tuntas & 8 & 80 \\
\hline \multicolumn{2}{c}{ Jumlah } & 10 & 100 \\
\hline
\end{tabular}

Tabel 4 menunjukkan bahwa persentase ketuntasan kelas sebesar $80 \%$ yaitu 8 siswa dari 10 termasuk dalam kategori tuntas dan $20 \%$ atau 2 siswa dari 10 termasuk dalam kategori tidak tuntas. Ini berarti terdapat 2 siswa yang perlu perbaikan karena belum mencapai kriteria ketuntasan individual.

b. Hasil Analisis Kualitatif

Pada siklus I tercatat sikap yang terjadi pada setiap siswa terhadap pelajaran matematika. Sikap siswa tersebut diperoleh dari lembar observasi pada setiap pertemuan yang dicatat pada setiap siklus. Lembar observasi tersebut untuk mengetahui perubahan sikap siswa selama proses belajar mengajar berlangsung di kelas.

Adapun sikap siswa dari siklus I adalah sebagai berikut :

1) Tampak masih banyak siswa yang tidak hadir mengikuti pelajaran baik itu tidak hadir tanpa keterangan maupun yang sakit.

2) Perhatian siswa masih berjalan seperti biasa seperti kurang antusiasnya siswa dalam menyelesaikan LKS secara kelompok dan masih kurangnya kerja sama siswa dalam membantu temannya menyelesaikan LKS secara kelompok.

3) Keaktifan siswa dalam proses belajar mengajar seperti menjawab pertanyaan, bertanya tentang materi yang sedang dibahas masih rendah. 
4) Kepasifan siswa dalam proses belajar mengajar masih tinggi, dalam hal ini mengajukan diri naik mengerjakan soal yang masih didominasi oleh siswa yang pintar dan itupun jika ditunjuk.

5) Saat siswa melakukan diskusi dengan anggota kelompoknya masih banyak siswa yang melakukan kegiatan lain sekitar 3-5 orang.

6) Siswa dalam mempersentasikan hasil diskusinya kurang serius dan tidak berani. Bahkan masih ada siswa yang belum siap untuk mempersentasikan hasil diskusi kelompoknya.

7) Pada saat persentasi hasil diskusi setiap kelompok diberikan kesempatan untuk menanggapi hasil diskusi kelompok lain. Pada siklus I masih kurang kelompok yang memberikan tanggapan terhadap hasil diskusi kelompok lain.

8) Selama siklus I berlangsung masih banyak siswa yang kurang perhatian untuk menyetor pekerjaan rumah dengan berbagai alasan yang mereka berikan.

c. Hasil Analisis Refleksi

Siklus I dilaksanakan 5 kali pertemuan dengan menerapkan pembelajaran kooperatif tipe NHT dengan berbagai macam metode yang digunakan dalam proses belajar mengajar. Pada siklus I tampak masih banyak siswa yang tidak hadir mengikuti pelajaran baik itu tidak hadir tanpa keterangan maupun yang sakit. Hal ini disebabkan karena siswa menganggap bahwa pelajaran matematika itu sulit dan rumit dengan rumus-rumusnya serta soal-soal matematika yang sulit diselesaikan.

Sebelum masuk pada materi pelajaran guru selalu menyampaikan tujuan pembelajaran kemudian memberikan motivasi kepada siswa agar siswa tertarik terhadap materi pelajaran tersebut, tetapi dengan begitu masih banyak siswa yang tidak memperhatikan guru. Sehingga dalam mengerjakan LKS tidak tahu harus bagaimana menyelesaikannya.

Pada setiap selesai satu kali pertemuan guru selalu memberikan pekerjaan rumah (PR) dengan tujuan agar siswa mau belajar dan melatih diri dalam menyelesaikan soal-soal yang ada dan dikumpul pada pertemuan berikutnya. Tetapi pada pertemuan berikutnya masih banyak siswa yang tidak meyelesaikan pekerjaan rumah tersebut dengan berbagai alasan yang mereka berikan.

Pembelajaran kooperatif pada fase terakhir adalah pemberian penghargaan kepada kelompok. Pada siklus I ini siswa dengan pemberian penghargaan pada kelompok belum dapat meningkatkan minat dan semangat siswa dalam mengikuti pelajaran. Hal ini disebabkan karena siswa baru mengenal model pembelajaran kooperatif yang sebelumnya tidak pernah digunakan oleh guru kelasnya.

\section{Siklus II}

a. Hasil Analisis Kuantitatif

Sama halnya pada siklus I, tes hasil belajar pada siklus II ini dengan pokok bahasan bilangan bulat dilaksanakan dengan bentuk ulangan harian. Hasil analisis kantitatif menunjukkan bahwa skor rata-rata yang dicapai oleh siswa yang diajarkan dengan menggunakan pendekatan kooperatif tipe NHT pada siklus II disajikan dalam Tabel 5 berikut.

Tabel 4 Statistik Skor Hasil Belajar Siswa Siklus II

\begin{tabular}{cc}
\hline Statistik & Nilai statistik \\
\hline Jumlah siswa & 10 \\
\hline Skor ideal & 100 \\
\hline Nilai maksimum & 95,00 \\
\hline Nilai minimum & 65,00 \\
\hline Rentang skor & 30,00 \\
\hline
\end{tabular}




\begin{tabular}{cc}
\hline Skor rata-rata & 80,00 \\
\hline Median & 80,00 \\
\hline Modus & 85,00 \\
\hline Standar deviasi & 9,13 \\
\hline
\end{tabular}

Dari tabel di atas skor rata-rata (mean) hasil belajar matematika siswa kelas V SD Negeri 75 Ujungpero Kecamatan Sabbangparu Kabupaten Wajo setelah diterapkan pembelajaran kooperatif tipe NHT pada siklus II adalah 80,00 dari skor ideal yang mungkin dicapai adalah 100. Dari skor rata-rata tersebut menunjukkan bahwa hasil belajar matematika siswa pada siklus II sebesar $80 \%$. Sekalipun sudah terjadi peningkatan pada siklus ini, namun masih terdapat siswa yang melakukan kegiatan lain selama proses pembelajaran berlansung.

Secara individual, skor yang dicapai siswa bervariasi dari skor minimum 65 dari terendah yang mungkin dicapai 0 sampai dengan skor maksimum 95 dari skor tertinggi (ideal) yang mungkin dicapai 100 dengan rentang skor 35,00. ini berarti bahwa hasil belajar matematika siswa cukup bervariasi dari skor hasil belajar yang sangat rendah (65) sampai dengan skor hasil belajar yang tinggi (90).

Apabila skor hasil belajar siswa dikelompokkan ke dalam 5 kategori maka diperoleh distribusi frekuensi nilai seperti pada Tabel 6 berikut.

Tabel 6. Distribusi Frekuensi dan Persentase Hasil Pada Siklus II

\begin{tabular}{cccc}
\hline Skor & Kategori & Frekuensi & $\begin{array}{c}\text { Persentase } \\
\mathbf{( \% )}\end{array}$ \\
\hline $0-34$ & Sangat Rendah & 0 & 0 \\
\hline $35-54$ & Rendah & 0 & 0 \\
\hline $55-64$ & Sedang & 0 & 0 \\
\hline $65-84$ & Tinggi & 6 & 60 \\
\hline $85-$ & Sangat tinggi & 4 & 40 \\
100 & & & \\
\hline & Jumlah & 10 & 100 \\
\hline
\end{tabular}

Tabel 6 menunjukkan bahwa skor rata-rata hasil belajar siswa setelah diberi tindakan pada siklus II berada pada kategori tinggi. Apabila hasil belajar siswa pada siklus II dianalisis, maka persentase ketuntasan belajar siswa pada siklus II dapat dilihat pada Tabel 7 berikut.

Tabel 7. Deskripsi Ketuntasan Belajar Siswa pada Siklus II

\begin{tabular}{cccc}
\hline $\begin{array}{c}\text { Persentase } \\
\text { skor }\end{array}$ & Kategori & Frekuensi & Persentase \\
\hline $0 \%-64 \%$ & Tidak tuntas & 0 & 0,00 \\
$65 \%-100 \%$ & Tuntas & 10 & 100,00 \\
\hline \multicolumn{2}{c}{ Jumlah } & 10 & 100 \\
\hline
\end{tabular}

Tabel 7 menunjukkan bahwa persentase ketuntasan kelas sebesar 100\% yaitu semua siswa termasuk dalam kategori tuntas.

b. Hasil analisis kualitatif

Selama penelitian, selain terjadi peningkatan hasil belajar matematika pada siklus I dan siklus II tercatat sejumlah perubahan yang terjadi pada setiap siswa terhadap pelajaran 
matematika. Perubahan tersebut diperoleh dari lembar observasi pada setiap pertemuan yang dicatat pada setiap siklus. Lembar observasi tersebut untuk mengetahui perubahan sikap siswa selama proses belajar mengajar berlangsung di kelas.

Adapun perubahan sikap siswa pada siklus II adalah sebagai berikut :

1. Tampak perubahan dengan ketidakhadiran siswa hampir tidak ada dibandingkan dengan siklus II.

2. Perhatian siswa tampak terjadi peningkatan pada saat mengerjakan LKS. Kekompakan antara anggota kelompok terjadi, dengan saling memberikan bantuan kepada anggota kelompok yang kurang memahami materi pelajaran. Hal tersebut disebabkan adanya penghargaan yang memotivasi mereka untuk saling bekerja sama dalam menyelesaikan LKS.

3. Keaktifan siswa sudah meningkat dalam proses belajar mengajar seperti menjawab pertanyaan, sudah berani bertanya dan berebutan menaikkan tangan untuk menjawab pertanyaan dari guru.

4. Kepasifan siswa dalam proses belajar mengajar sudah rendah, dalam hal ini siswa sudah berani menjawab pertanyaan serta mengerjakan soal dipapan tulis tanpa ditunjuk.

5. Pada saat siswa melakukan diskusi dengan anggota kelompoknya, siswa yang melakukan kegiatan lain sudah rendah sekitar 1-2 orang.

6. Siswa dalam mempersentasikan hasil diskusinya siswa sudah tampak berani dan serius dalam memberikan penjelasan terhadap hasil diskusi kelompok.

7. Pada saat persentasi hasil diskusi setiap kelompok diberikan kesempatan untuk menanggapi hasil diskusi kelompok lain. Siswa sudah tampak berani dan serius dalam memberikan penjelasan terhadap hasil diskusi kelompok.

8. Perhatian siswa sudah meningkat dengan ditandai banyaknya siswa yang menyetor pekerjaan rumah dan tidak ada lagi siswa yang tidak mengerjakan pekerjaan rumah.

c. Hasil analisis refleksi.

Pada siklus dilaksanakan 5 kali pertemuan dengan menerapkan pembelajaran yang sama dengan berbagai macam metode yang digunakan dalam proses belajar mengajar. Lain halnya pada siklus II kehadiran siswa hampir tidak ada yang tidak hadir mengikuti pelajaran. Hal ini disebabkan karena rasa ingin tahu siswa terhadap matematika yang sebelumnya dianggap sulit itu ternyata mudah. Sehingga timbul semangat untuk mengikuti pelajaran.

Begitu pula perhatian siswa semakin antusias saja dalam menerima materi pelajaran. Sehingga dalam mengerjakan LKS yang diberikan dikerjakan dengan baik dan lancar meskipun masih ada yang bertanya dan mengganggu teman kelompoknya. Sama halnya pada pemberian PR hampir semua siswa mengerjakan dan mengumpulnya meskipun itu dikerja di sekolah. Pada siklus II ini semangat dan minat siswa semakin meningkat dengan adanya penghargaan yang diberikan sehingga dapat memotivasi siswa dalam proses belajar mengajar.

\section{Analisis Refleksi Siswa}

Dari hasil analisis terhadap refleksi dan tanggapan siswa dapat disimpulkan ke dalam kategori sebagai berikut :

1. Pendapat siswa tentang pelajaran matematika.

Sebagian siswa berpendapat bahwa pelajaran matematika merupakan pelajaran yang kadang-kadang mudah dimengerti juga kadang-kadang sulit dipahami mulai dari berhitung sampai penggunaan rumusnya. Oleh karena itu diperlukan keseriusan, konsentrasi dan disiplin yang tinggi.Adapula yang berpendapat bahwa kesenangan terhadap pelajaran matematika relatif artinya pada saat materi pelajaran yang diajarkan mudah mereka senang belajar. Tetapi jika materi yang diajarkan sulit maka mereka kurang senang menerima materi pelajaran. 
Selain itu dalam mempelajari matematika diperlukan banyak latihan dalam menyelesaikan soal-soal, agar dapat meningkatkan daya nalar. Dengan mempelajari matematika dapat mengetahui banyak rumus dan simbol-simbol. Sehingga dengan mempelajari matematika semua pelajaran yang lain mudah dipahami.

2. Bagaimana motivasi/semangat siswa dalam belajar matematika setelah digunakan model Cooperatif Learning/pembelajaran kooperatif tipe NHT.

Untuk hal ini pada umumnya siswa menanggapi positif tentang penerapan pembelajaran kooperatif tipe NHT, karena dengan model pembelajaran tersebut siswa dapat belajar bekerja sama menyelesaikan tugas yang diberikan oleh guru sehingga siswa yang merasa kurang memahami materi dapat bertanya kepada siswa yang lebih mengetahui. Dengan adanya kerjasama antara siswa maka bukan hanya akan terjadi interaksi antar siswa tetapi juga interaksi antar siswa dan guru.

Begitu pula dengan adanya penghargaan yang diberikan guru kepada siswa dapat meningkatkan minat dan semangat siswa dalam mengikuti pembelajaran. Hal tersebut terlihat pada saat proses belajar mengajar berlansung yaitu semua kelompok berlomba-lomba menyelesaikan LKS yang diberikan.

3. Bagaimana hambatan dalam belajar matematika dengan menggunakan model pembelajaran kooperatif tipe NHT.

Hambatan siswa dalam belajar matematika dengan menggunakan model pembelajaran kooperatif tipe NHT adalah : Pemahaman siswa masih kurang dikarenakan kurangnya contoh-contoh soal yang diberikan oleh guru, penyaiian materi terlalu cepat sehingga siswa masih kurang mengerti, masih kurangnya sarana dan prasarana pendukung dalam meningkatkan proses belajar mengajar, dalam proses pengajaran model pembelajaran kelompok tipe NHT membutuhkan waktu yang banyak.

4. Bagaimana saran yang diajukan siswa terhadap guru dalam mengajarkan matematika.

Pada umumnya siswa menyarankan bahwa untuk lebih memahami materi pelajaran sebaiknya diberikan contoh, agar mereka lebih mengerti, mudah mengerjakan soal dan tidak mudah lupa, s

ebagian juga menyarankan bahwa dalam menyajikan materi jangan terlalu cepat agar lebih mudah dimengerti.

\section{PEMBAHASAN}

Dalam penelitian ini diterapkan pembelajaran kooperatif tipe NHT yang terdiri dari dua siklus. Penelitian ini membuahkan hasil yang signifikan yakni meningkatnya kualitas proses dan hasil belajar matematika di SD Negeri 75 Ujungpero Kecamatan Sabbangparu Kabupaten Wajo. Peningkatan yang terjadi dilihat dari Tabel 8.

Tabel 8. Perbandingan Hasil Belajar pada Siklus I dan Siklus II.

\begin{tabular}{ccccccccc}
\hline & \multicolumn{4}{c}{ Nilai perolehan dari 45 siswa } & \multicolumn{3}{c}{ Ketuntasan } \\
\cline { 2 - 8 } $\begin{array}{c}\text { Sikl } \\
\text { us }\end{array}$ & $\begin{array}{c}\text { Mak } \\
\mathrm{s}\end{array}$ & Min & $\begin{array}{c}\text { Mea } \\
\mathrm{n}\end{array}$ & $\begin{array}{c}\text { Media } \\
\mathrm{n}\end{array}$ & $\begin{array}{c}\text { Mod } \\
\text { us }\end{array}$ & $\begin{array}{c}\text { StDe } \\
\mathrm{v}\end{array}$ & $\begin{array}{c}\text { Tunt } \\
\text { as }\end{array}$ & $\begin{array}{c}\text { Tida } \\
\text { Tunt } \\
\text { as }\end{array}$ \\
\hline I & $\begin{array}{c}80,0 \\
0\end{array}$ & $\begin{array}{c}40,0 \\
0\end{array}$ & $\begin{array}{c}64,5 \\
0\end{array}$ & 67,50 & 70,00 & 14.03 & 8 & 2 \\
\hline II & $\begin{array}{c}95,0 \\
0\end{array}$ & $\begin{array}{c}65,0 \\
0\end{array}$ & $\begin{array}{c}80,0 \\
0\end{array}$ & 80,00 & 85,00 & 9,13 & 10 & 0 \\
\hline
\end{tabular}


Berdasarkan hasil deskriptif Tabel 8 di atas menunjukkan bahwa setelah dilaksanakan dua kali tes, banyaknya siswa yang tuntas secara perorangan pada siklus I adalah 8 orang meningkat menjadi 10 orang pada siklus II. Ditinjau secara klasikal peningkatannya adalah $80 \%$ pada siklus I meningkat menjadi $100 \%$ pada siklus II yang bila dikategorisasikan berada pada kategori baik. Sedangkan peningkatan kualitas proses belajar siswa pada hasil observasi menunjukkan pada siklus I rendah, hal ini disebabkan siswa belum terbiasa dengan strategi pembelajaran yang diterapkan, akibatnya hasil belajar matematika juga rendah. Pada siklus II terjadi peningkatan kualitas proses belajar mengajar yang diikuti dengan peningkatan hasil belajar matematika. Hal ini disebabkan siswa mulai beradaptasi dengan strategi pembelajaran yang diterapkan, selain itu siswa lebih termotivasi dengan penghargaan dalam bentuk materi.

Hasil pengamatan menunjukkan bahwa keterampilan sosial dalam belajar kelompok secara kooperatif masih perlu ditingkatkan terutama menjalin kerjasama yang baik dan membagi membagi tugas dengan proporsi yang sama besar. Dengan peningkatan keterampilan sosial akan lebih memudahkan siswa dalam mengkonstruksi pengetahuannya sendiri. Rencana pelaksanaan tindakan dalam penelitian ini sesuai dengan waktu yang diberikan, namun waktu yang digunakan kenyataannya tidak cukup dalam pelaksanaan proses belajar mengajar di kelas.

Hasil penelitian ini sejalan dengan hasil penelitian Nursyamsi 2016 dengan hasil penelitian bahwa strategi pembelajaran memiliki efek pada retensi. Skor rata dikoreksi dari strategi pembelajaran NHT adalah 24,03\% lebih tinggi dibandingkan dengan pembelajaran konvensional, sedangkan hasil penelitian Mayong 2016 dengan hasil penelitian bahwa peningkatan hasil belajar pada siklus I adalah 44\% yang dikategorikan sebagai baik baik, 56\% adalah sangat baik, dan tidak ada siswa kategori rendah. Siklus II, 84\% diklasifikasikan sebagai sangat baik, 16\% dikelompokkan sebagai baik, dan tidak ada yang tergolong rendah.

\section{SIMPULAN DAN SARAN \\ Simpulan}

Berdasarkan hasil analisis data dan pembahasan maka dapat ditarik kesimpulan bahwa Pembelajaran kooperatiftipe NHT cocok diterapkan pada siswa kelas V SD Negeri 75 Ujung pero Kecamatan Sabbang paru Kabupaten Wajo. Hal tersebut dapat dilihat dari meningkatnya hasil belajar siswa setelah diadakan pengembangan pembelajaran kooperatiftipe NHT. Hasil belajar yang diperoleh dari tesakhir siklus, pada akhir siklus I dengan skor rata-rata 64,50 dari skor ideal 100 dengan standar deviasi 14,03, sedangkan pada akhirsi klus II dengan skor rata-rata 80 dari skor ideal 100 dengan standar deviasi 9,13. Terjadi perubahan sikap siswa selama proses pembelajaran sesuai dengan hasil observasi yaitu dengan adanya penerapan model pembelajaran kooperatiftipe NHT dapat meningkatkan rasa percaya diri siswa untuk bertanya baik kepada guru maupun kepada temannya tentang materi yang tidak dimengerti serta dapat meningkatkan kehadiran siswa.

Berdasarkan hasil yang diperoleh dari penelitian ini, maka menyarankan kepada guru matematika khususnya agar dapat mencoba menerapkan model pembelajaran kooperatiftipe NHT dalam proses belajar mengajar agar dapat meningkatkan hasil belajar siswa. Guru matematika sebaiknya kreatif dalam menciptakan suasana kelas agar siswa tidak cepat bosan dan tegang dalam belajar serta lebih termotivasi untuk memperhatikan apa yang diajarkan. Kepada pihak sekolah agar memaksimalkan sarana dan prasarana di sekolah, misalnya peningkatan kualitas dan kuantitas buku-buku perpustakaan, sehingga siswa yang tidak memiliki buku pelajaran belajarnya tidak terhambat dengan meminjam keperpustakaan. Diharapkan kepada peneliti yang akan melakukan penelitian sebaiknya mengambil satu permasalahan misalnya kombinasi antara model pembelajaran kooperatiftipe NHT ini dengan salah satu metode pembelajaran, untuk mengetahui apa dengan penerapannya dapat meningkat kanhasil belajar siswa. 


\section{DAFTAR PUSTAKA}

Depdiknas.(2003). Kurikulum 2004 Standar Kompetensi Sekolah Dasar. Jakarta : Depdiknas.

Lorina, Pirade. (2012). Penerapan Model Pembelajaran Kooperatif Tipe Numbered Head Together Berbantuan Media Gambar untuk Meningkatkan Hasil Belajar Siswa Pada Mata Pelajaran IPA Di Kelas IV SDN No. 1 Tanjung Padang: Palu. Universitas Tadulako. Elementary School of Education E-Journal, Media Publikasi Ilmiah Prodi PGSD Vol 2, Nomor 2, Juni 2014.

Mayong Maman.(2016). The Implementation of Cooperative Learning Model Number Heads Together (NHT)' in Im proving the Students' Ability in Reading Comprehension. International Journal of Evaluation and Research in Education (IJERE) Vol.5, No.2, June 2016, pp. 174 180 ISSN: 2252-8822.

Nursyamsi. (2016). The Effect Of Numbered Heads Together (NHT) Learning Strategy on the Retention of Senior High School Students In Muara Badak, East Kalimantan, Indonesia. European Journal of Education Student. Volume 2, Issue 5, 2016.

Rusman. (2012). Model-Model Pembelajaran. Depok : PT Rajagrafindo Persada.

Salam, S.M. (2003). Peningkatan Hasil Belajar Matematika Melalui Model Pembelajaran Kooperatif Dengan Tipe STAD Pada Siswa Kelas I SMU Negeri 3 Takalar. Skripsi. Tidak diterbitkan. Makassar, FKIP: Unismuh Makassar.

Standar Kompetensi Mata Pelajaran Matematika SD \& MI Standar Kompetensi Kurikulum. (2003). Departemen Pendidikan Nasional.

Suherman, Erman Dkk. (2003). Strategi Pembelajaran Matematika Kontemporer. Bandung:Jurusan Pendidikan Matematika FMIPA Universitas Pendidikan Indonesia. 